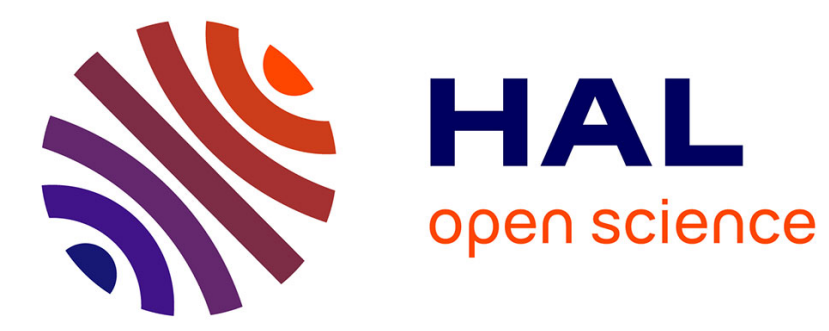

\title{
Use of asbestos-free fiber-cement waste as a partial substitute of Portland cement in mortar
}

\author{
Samir Bouharoun, Nordine Leklou, Pierre Mounanga
}

\section{To cite this version:}

Samir Bouharoun, Nordine Leklou, Pierre Mounanga. Use of asbestos-free fiber-cement waste as a partial substitute of Portland cement in mortar. Materials and structures, 2014, 48 (6), pp.1679 1687. 10.1617/s11527-014-0264-0 . hal-01007413

\section{HAL Id: hal-01007413 \\ https://hal.science/hal-01007413}

Submitted on 18 Jan 2017

HAL is a multi-disciplinary open access archive for the deposit and dissemination of scientific research documents, whether they are published or not. The documents may come from teaching and research institutions in France or abroad, or from public or private research centers.
L'archive ouverte pluridisciplinaire HAL, est destinée au dépôt et à la diffusion de documents scientifiques de niveau recherche, publiés ou non, émanant des établissements d'enseignement et de recherche français ou étrangers, des laboratoires publics ou privés. 


\title{
Use of asbestos-free fiber-cement waste as a partial substitute of Portland cement in mortar
}

\author{
Samir Bouharoun • Nordine Leklou $\cdot$ Pierre Mounanga \\ Research Institute in Civil Engineering and Mechanics, CNRS UMR 6183, University of Nantes - IUT of Saint-Nazaire GeM, \\ LUNAM University, Nantes, France
}

\begin{abstract}
This work aims to study the possibility to use asbestos-free fiber-cement waste in substitution of ordinary Portland cement for the production of mortars. The fiber-cement particles were incorporated in mortars in partial replacement of cement, with mass substitution rates of 5 and $20 \%$. Cement hydration rate, workability, total shrinkage, porosity accessible to water and mechanical performances of mortars made with ground fiber-cement were measured and compared with the properties of control paste and mortar (free of fiber-cement). The results showed that the presence of fiber-cement extended by 5-10\% the dormant period of the binder hydration, when compared to that of Portland cement, depending on the substitution rate considered. Furthermore, at 28 days, the replacement of cement with 5 and $20 \%$ of fibercement caused a reduction of 14-35\% in compressive strength, when compared to the reference mortar performances. This decrease was greater than that observed on mortars containing limestone filler with the same substitution rate of cement. However, the strengths obtained were acceptable for structural applications.
\end{abstract}

Keywords Portland cement · Fiber-cement . Limestone filler - Waste recovery $\cdot$ Mortars · Hydration rate $\cdot$ Mechanical properties

\section{Introduction}

Asbestos-free fiber-cement is a relatively new building material: the first fiber-cement products have been incorporated as roof elements for construction about 30 years ago. The fiber-cement is a composite material made from cement, cellulose fibers, admixtures and water. Each year, the cutting of fiber-cement panels during the production process generated several hundreds of tons of waste [1]. These wastes contain a high dosage of unhydrated cement whose hydraulic activity could be exploited in mortar or concrete manufacturing. In addition, the valorization of these wastes could reduce the environmental cost of construction materials. This can be attained through maximizing the recycling of waste products in construction materials, currently simply used as landfill [2].

Today, the recovery of such wastes is an economical alternative feasible in different applications, but they must satisfy the same requirements in terms of quality and performance than traditional materials. Although extensive research has been done on recycled concrete materials over the last decades [3-6], there have been very few studies concerning the formulation of mortars or concretes which 
incorporates waste fiber-cement. Recently, Müller et al. [1] conducted a study on the use of crushed asbestos-free fiber-cement waste as aggregate base layer for road structures. Their results were encouraging and allowed to introduce this type of waste in the field construction.

The objective of this study is to evaluate experimentally the properties at fresh and hardened state of mortars made with fiber-cement wastes. The effects of these wastes were compared to those of limestone filler commonly used in the manufacture of cementitious materials. For this purpose, several pastes and mortars incorporating fiber-cement and limestone filler at different dosages (5 and $20 \%$ partial replacement of Portland cement) were prepared and investigated. The contribution of these materials was assessed on the properties at early age (including hydration heat rate), mechanical strength, Young's modulus, porosity accessible to water, total shrinkage and mass loss by drying.

\section{Materials and mixtures}

\subsection{Cement}

The cement used in this study was a CEM I 52.5 R, in accordance with European standard [7] from Saint Pierre La Cour plant (France). Its density was $3,140 \mathrm{~kg} / \mathrm{m}^{3}$ and its Blaine fineness of $440 \mathrm{~m}^{2} / \mathrm{kg}$. The chemical composition of the cement is given in Table 1. Application of Bogue's formulas to the chemical composition of the cement gave the following mass distribution of the main phases: $61 \%$ of $\mathrm{C}_{3} \mathrm{~S}$, $15 \%$ of $\mathrm{C}_{2} \mathrm{~S}, 8 \%$ of $\mathrm{C}_{3} \mathrm{~A}$ and $10 \%$ of $\mathrm{C}_{4} \mathrm{AF}$.

Table 1 Chemical composition of cement (mass\%)

\begin{tabular}{lc}
\hline Cement & Massic content $(\%)$ \\
\hline $\mathrm{SiO}_{2}$ & 20.07 \\
$\mathrm{Al}_{2} \mathrm{O}_{3}$ & 4.86 \\
$\mathrm{Fe}_{2} \mathrm{O}_{3}$ & 3.07 \\
$\mathrm{CaO}$ & 64.25 \\
$\mathrm{MgO}$ & 0.95 \\
$\mathrm{SO}_{3}$ & 3.55 \\
$\mathrm{~K}_{2} \mathrm{O}$ & 1.00 \\
$\mathrm{Na}_{2} \mathrm{O}$ & 0.20 \\
$\mathrm{Na}_{2} \mathrm{O}_{\text {eq }}$ & 0.85 \\
\hline
\end{tabular}

\subsection{Sand}

Standardized siliceous sand of Leucate (France), was used for the manufacture of mortars [8]. The particle size of sand ranged between 0 and $2 \mathrm{~mm}$. Its density was $2,600 \mathrm{~kg} / \mathrm{m}^{3}$.

\subsection{Limestone filler}

Two pastes and two mortars were made with a mixture of limestone filler and cement to compare the effects of this mineral addition with those of fiber-cement. The limestone filler (LF) used was a BETOCARB P2, produced at Erbray's plant (France), its $\mathrm{CaCO}_{3}$ content was $97.30 \%$. This limestone filler was characterized by a Blaine fineness of $397 \mathrm{~m}^{2} / \mathrm{kg}$, an absolute density of $2,710 \mathrm{~kg} / \mathrm{m}^{3}$ and a water content of $0.1 \%$.

\subsection{Fiber-cement}

The fiber-cement is a composite material made from cement (70-80\%), cellulose fibers (5-10\%), admixtures and water. Considering the low dosage of used water, a significant amount of cement remains at the anhydrous state in the final material. The fiber-cement could therefore present a hydraulic potential, favorable to the development of cement mortar performances. Wastes of fiber-cement studied are in the form of flat and long thin slab with a few millimeters thick and several centimeters long (Fig. 1).

They were initially ground to increase the contact surface between water and non-hydrated cement particles. Then, they were sieved on a column of two sieves $(80$ and $100 \mu \mathrm{m})$ in order to obtain three different particle sizes, smaller than $80 \mu \mathrm{m}$ (denoted AFFC- $80 \mu \mathrm{m}$ ), between 80 and $100 \mu \mathrm{m}$ (denoted AFFC $-100 \mu \mathrm{m}$ ) and bigger than $100 \mu \mathrm{m}$ (denoted AFFC- $>100 \mu \mathrm{m}$ ).

The water content, the specific surface and absolute density of the different ground fiber-cement grades, measured by pycnometry, are given in Table 2 .

The particle size distributions of cement, fibercement and limestone filler measured using Laser granulometry are shown in Fig. 2. The fractions of the different size classes are summarized in Table 3 . The key point that emerged from these results was a greater fineness of limestone filler compared to that of cement and fiber-cement. 

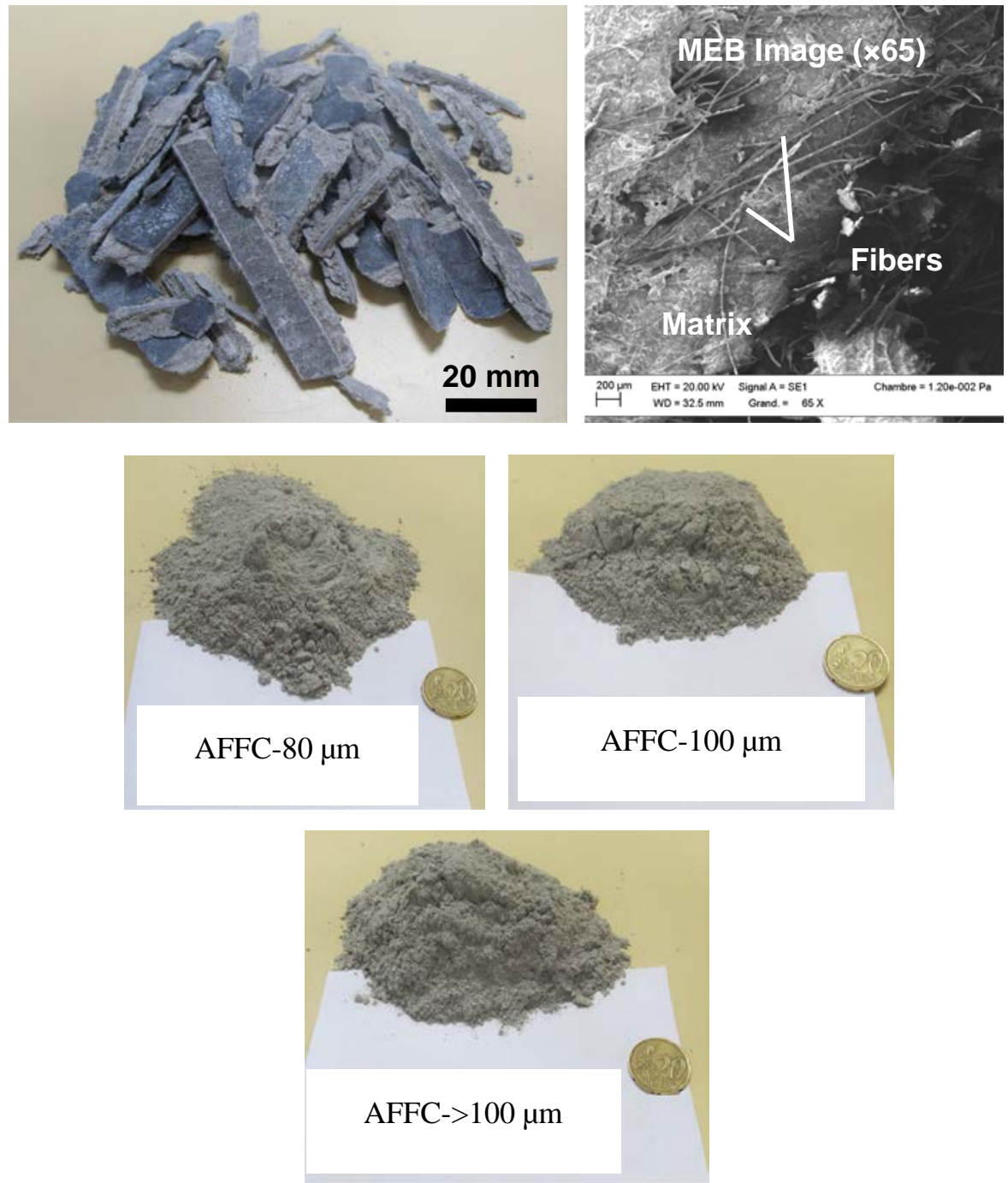

Fig. 1 Fiber-cement wastes at raw state and after mechanical treatment (grinding and sieving) (AFFC-80 $\mu \mathrm{m}$, AFFC-100 $\mu \mathrm{m}$ and AFFC- $>100 \mu \mathrm{m})$

Table 2 Physical characteristics of fiber-cement

\begin{tabular}{llll}
\hline & $\begin{array}{l}\text { Water } \\
\text { content }(\%)\end{array}$ & $\begin{array}{l}\text { Density } \\
\left(\mathrm{kg} / \mathrm{m}^{3}\right)\end{array}$ & $\begin{array}{l}\text { Specific } \\
\text { surface } \\
\left(\mathrm{cm}^{2} / \mathrm{g}\right)\end{array}$ \\
\hline AFFC-80 $\mu \mathrm{m}$ & 2.4 & 2,250 & 5,617 \\
AFFC-100 $\mathrm{m}$ & 2.3 & 2,230 & 4,833 \\
AFFC- $>100 \mu \mathrm{m}$ & 2.6 & 2,190 & 2,673 \\
\hline
\end{tabular}

\subsection{Mixtures and curing conditions}

Eight mortars and eight cement pastes were made and mixed according to the European standard [8] with a water/binder mass ratio (W/B) of 0.60 . For mortars, the sand/binder mass ratio was equal to 3 . In this paper, the term "binder" indicates the cement, used alone in the case of the control mortar $(\mathrm{C}-100 \%)$, or the binary mixture of cement and fiber-cement (AFFC- $80 \mu \mathrm{m}-$ $5 \%, \quad$ AFFC- $80 \mu \mathrm{m}-20 \%$, AFFC-100 $\mu \mathrm{m}-5 \%$, AFFC-100 $\mu \mathrm{m}-20 \%$ and AFFC->100 $\mu \mathrm{m}-20 \%$ ) or the binary mixture of cement and limestone filler (LF-5 \% and LF-20 \%). The binary binders were made by substituting 5 or $20 \%$ of cement mass by fiber-cement or limestone filler. The compositions of the binder mortars and pastes are given in Table 4.

Workability tests using mortar maniabilimeter LCPC [9] and measurements of total shrinkage [10], water-accessible porosity [11], dynamic 
Fig. 2 Size distribution of Portland cement (C), limestone filler (LF) and fiber-cement (AFFC- $80 \mu \mathrm{m}$, AFFC-100 $\mu \mathrm{m}$ and AFFC$>100 \mu \mathrm{m})$

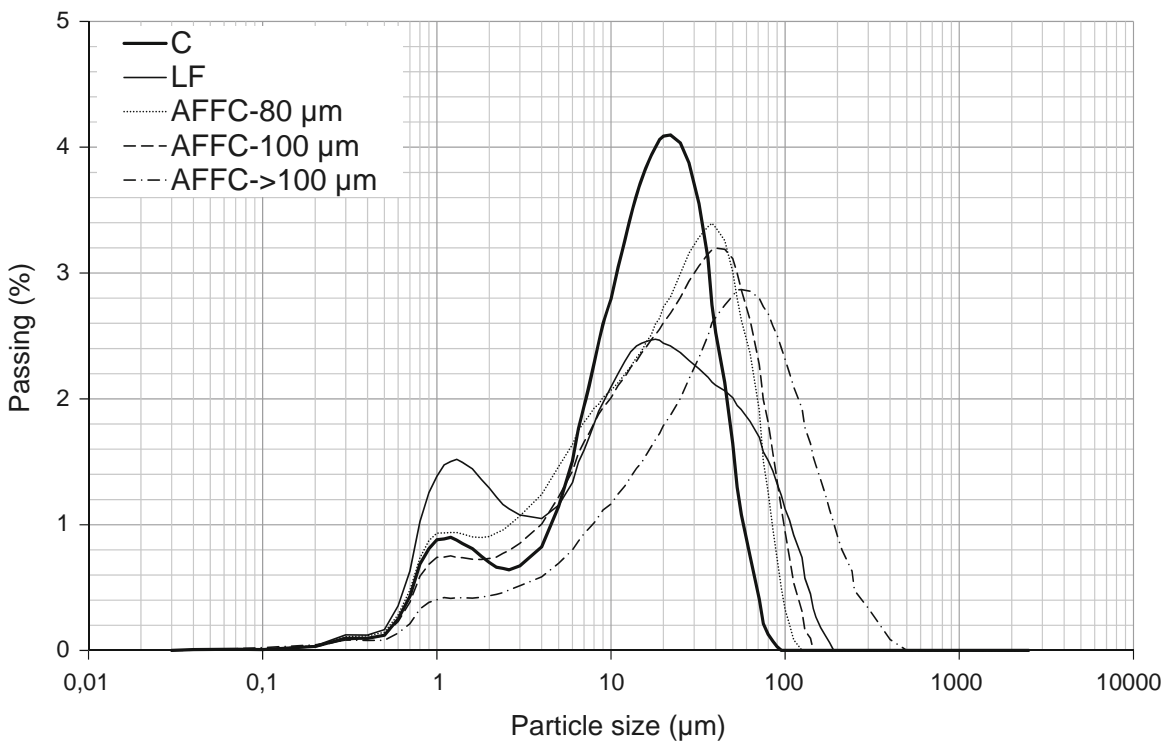

Table 3 Particle size classes of Portland cement (C), limestone filler (LF) and fiber-cement (AFFC-80 $\mu \mathrm{m}$, AFFC-100 $\mu \mathrm{m}$, AFFC$>100 \mu \mathrm{m})$

\begin{tabular}{llllll}
\hline & C & LF & AFFC-80 $\mu \mathrm{m}$ & AFFC-100 $\mu \mathrm{m}$ & AFFC->100 $\mu \mathrm{m}$ \\
\hline $90 \%$ of particles with $\varnothing$ inferior or equal to & $37.4 \mu \mathrm{m}$ & $66.0 \mu \mathrm{m}$ & $53.0 \mu \mathrm{m}$ & $63.0 \mu \mathrm{m}$ & $120.0 \mu \mathrm{m}$ \\
$50 \%$ of particles with $\varnothing$ inferior or equal to & $14.3 \mu \mathrm{m}$ & $13.5 \mu \mathrm{m}$ & $16.0 \mu \mathrm{m}$ & $18.7 \mu \mathrm{m}$ & $35.0 \mu \mathrm{m}$ \\
$10 \%$ of particles with $\varnothing$ inferior or equal to & $1.6 \mu \mathrm{m}$ & $1.2 \mu \mathrm{m}$ & $1.5 \mu \mathrm{m}$ & $1.8 \mu \mathrm{m}$ & $3.4 \mu \mathrm{m}$ \\
\hline
\end{tabular}

Young's modulus [12] and mechanical strength [8] were performed on mortars. In addition, hydration heat was measured on pastes using isothermal microcalorimetry [13]. The mortars were poured in metal molds with $40 \times 40 \times 160 \mathrm{~mm}^{3}$ of dimensions, some of them being equipped with stainless steel studs for the measurement of total shrinkage. Fresh paste samples were collected and placed in bottles to measure the heat of hydration. The properties of mixtures incorporating ground fibercement or limestone filler were then compared to those of the control mortar and paste made with pure cement.

After pouring, the molds $40 \times 40 \times 160 \mathrm{~mm}^{3}$ were stored in a humidity chamber during $24 \mathrm{~h}$ at $20 \pm 1{ }^{\circ} \mathrm{C}$ and at a relative humidity above $90 \%$. After $24 \mathrm{~h}$, the specimens were demolded. Those manufactured for mechanical tests were kept in the humidity chamber. The specimens dedicated to the measurement of total shrinkage and Young's modulus were kept in a room at $20 \pm 1{ }^{\circ} \mathrm{C}$ and $50 \pm 5 \%$ of relative humidity.

\section{Experimental procedures}

\subsection{Hydration heat}

The heat flux due to the hydration reactions of cement pastes was measured at $20{ }^{\circ} \mathrm{C}$ using a multi-channel isothermal microcalorimeter of TAM Air type. After mixing, two samples were immediately taken from the mixture, placed in bottles, weighed and loaded into the microcalorimeter. The heat release of samples characterizing the reaction rate of binder was measured automatically to quantify the influence of fiber-cement and limestone filler on the early-age binder reactivity. Curves of heat flow normalized to the mass of binder (cement, fiber-cement and limestone filler) and presented in the paper are average curves obtained from two parallel tests.

\subsection{Mass variations and total shrinkage}

Total shrinkage and mass variation of mortar specimens were measured using respectively an 
Table 4 Composition parameters, density at fresh state and flow time with a LCPC-maniabilimeter of the different mortars investigated (the indicated ratios are mass ratios, C-100: cement; AFFC-80 $\mu \mathrm{m}$ : ground fiber-cement below $80 \mu \mathrm{m}$;
AFFC-100 $\mu \mathrm{m}$ : ground fiber-cement sieved between 80 and $100 \mu \mathrm{m}$; AFFC->100 $\mu \mathrm{m}$ : not sieved ground fiber-cement; LF: limestone filler; B: binder)

\begin{tabular}{|c|c|c|c|c|c|c|c|c|}
\hline Mortars & $\mathrm{C}-100 \%$ & $\begin{array}{l}\text { AFFC-80 } \\
\mu \mathrm{m}-5 \%\end{array}$ & $\begin{array}{l}\text { AFFC-80 } \\
\mu \mathrm{m}-20 \%\end{array}$ & $\begin{array}{l}\text { AFFC-100 } \\
\mu \mathrm{m}-5 \%\end{array}$ & $\begin{array}{l}\text { AFFC-100 } \\
\mu \mathrm{m}-20 \%\end{array}$ & $\begin{array}{l}\text { AFFC }->100 \\
\mu \mathrm{m}-20 \%\end{array}$ & LF-5 \% & LF-20\% \\
\hline $\mathrm{C} / \mathrm{B}$ & 1.00 & 0.95 & 0.80 & 0.95 & 0.80 & 0.80 & 0.95 & 0.80 \\
\hline AFFC- $80 \mu \mathrm{m} / \mathrm{B}$ & - & 0.05 & 0.20 & - & - & - & - & - \\
\hline AFFC-100 $\mu \mathrm{m} / \mathrm{B}$ & - & - & - & 0.05 & 0.20 & - & - & - \\
\hline AFFC->100 $\mu \mathrm{m} / \mathrm{B}$ & - & - & - & - & - & 0.20 & - & - \\
\hline $\mathrm{LF} / \mathrm{B}$ & - & - & - & - & - & - & 0.05 & 0.20 \\
\hline $\begin{array}{l}\text { Density at fresh } \\
\text { state }(-)\end{array}$ & 2.314 & 2.300 & 2.273 & 2.300 & 2.258 & 2.256 & 2.301 & 2.298 \\
\hline Flow time (s) & 3 & 4 & 5 & 4 & 5 & 6 & 3 & 3 \\
\hline
\end{tabular}

extensometer with $1 \mu \mathrm{m}$ of precision and a balance with $0.01 \mathrm{~g}$ of precision. Each average curve was obtained from three parallel tests. The measurements were conducted from 1 day after the casting of mortars up to 90 days of drying.

\subsection{Dynamic Young's modulus and mechanical strengths at 28 days}

Dynamic Young's modulus was measured on the mortar specimens according to European standard [12]. Measurement consisted in determining the sample density and the fundamental transverse resonant frequency of mortars. This frequency was determined with an impulse excitation technique using a Grindosonic $^{\circledR}$ device. The operation consisted in performing a slight elastic shock on the specimen and analyzing the phenomenon of transient vibration that follows. Then, the fundamental transverse resonant frequency was determined electronically. For each mortar, the determination of Young's modulus was performed on three specimens manufactured from the same mixture. The flexural and compressive strength were determined according to the procedure of European standard [8]. Reported data for each mortar represent the average values obtained from three tests for flexural strength, and four tests for compressive strength.

\subsection{Water-accessible porosity}

The open porosity of mortars was determined on half-specimens resulting from the flexural tests using a procedure based on that recommended by [11].
Each sample of mortar was previously dried for about 2 weeks in a drying oven at $60 \pm 2{ }^{\circ} \mathrm{C}$. It was stopped when the mass variation became lower than $0.05 \%$. The sample was then saturated with water and under vacuum for $48 \mathrm{~h}$. At the end of the saturation sequence, it was weighed and its volume was determined using hydrostatic weighing. The porosity $P$ was then calculated using the following formula:

$P=\frac{M_{\mathrm{sat}}-M_{\mathrm{dry}}}{\rho_{\text {water }} V}$

where $M_{\text {sat }}$ is the mass of saturated mortar sample (g); $M_{\text {dry }}$ is the mass of dry sample (g); $V$ is the volume of sample $\left(\mathrm{cm}^{3}\right) ; \rho_{\text {water }}$ is the density of water $\left(\mathrm{g} / \mathrm{cm}^{3}\right)$. For each mortar composition, two half-specimens were tested in order to calculate an average value of open porosity accessible to water.

\section{Results and discussion}

\subsection{Hydration rate}

Figures 3 and 4 present the curves of hydration heat and heat flow evolution of mortars as a function of time at 5 and $20 \%$ of substitutions rate of cement mass. Due to dilution effect $[14,15]$, the heat generated by the pastes containing fiber-cement or limestone filler was lower than that generated by pure cement paste (C-100 \%).

The decrease in both heat flow and reaction heat was accentuated when the substitution degree of cement with fiber-cement or limestone filler increased. 


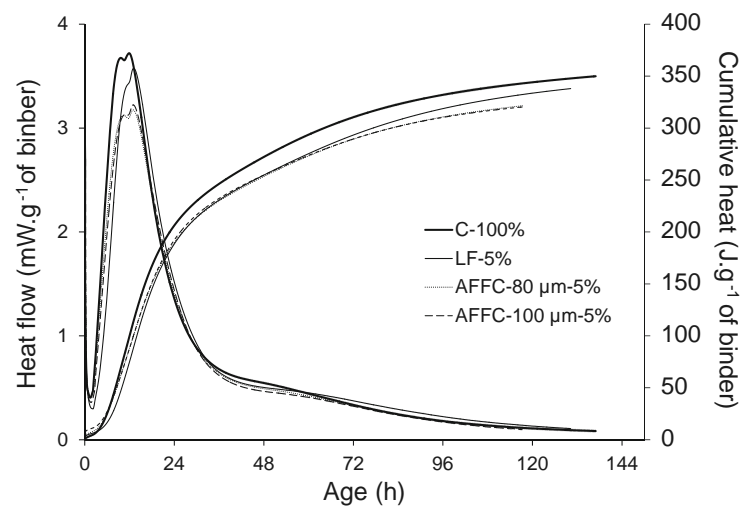

Fig. 3 Evolution of heat flow and hydration heat as a function of time for $5 \%$ of substitution degree of cement

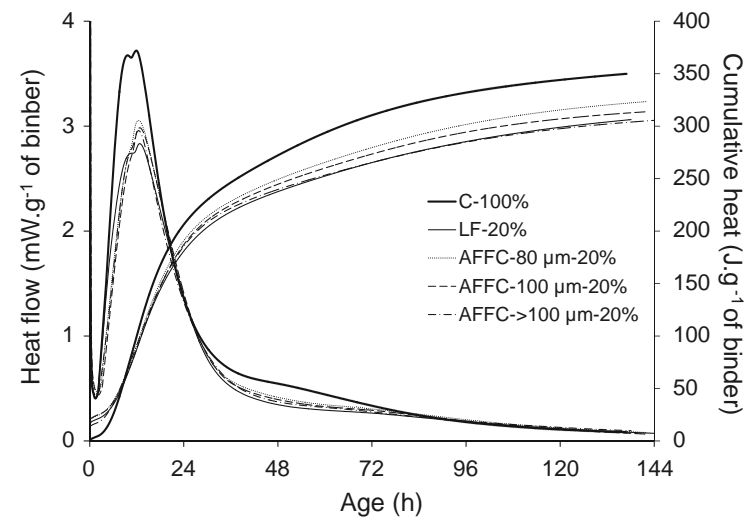

Fig. 4 Evolution of heat flow and hydration heat as a function of time for a cement substitution rate of $20 \%$

The results also show a delay in the appearance of the main peak of hydration of microcalorimetry curves of binary binders, compared to that of the microcalorimetry curve of pure cement (Table 5). This indicates in particular that, for cementitious systems considered, the mineral additions studied had a tendency to extend the dormant phase of hydration. It is important to note that delays caused by the presence of fiber-cement and limestone filler were comparable for a given rate of substitution. Moreover, the fineness of fiber-cement seems to have a little influence on the hydration rate of pastes for a given dosage of fiber-cement.

\subsection{Mass and dimensional variations}

Figures 5 and 6 present the evolutions of total shrinkage and mass variation for different specimens of mortars studied, respectively.

The shrinkage curves show two phases: the first is a phase of rapid shrinkage occurring during the first 4 weeks of exposure to drying, followed by a second phase of slower shrinkage. Considering the relatively high initial W/B ratio (0.6), we can consider that these deformations were mainly related to tensile forces exerted by the water meniscus caused by the desiccation of the porous network of mortars [16]. The internal capillary tension induces an overall compression of the mineral skeleton leading to the deformations of shrinkage. Thus, the profile of shrinkage curves can be correlated to the evolution curves of mass variations. Indeed, we denote, on these curves, two distinct phases, corresponding approximately to those observed on the shrinkage curves: during the first phase of about 4 weeks, the rate of water evaporation was high. Beyond this age, the change in mass of specimens was very low, even almost zero. We observe however that, despite this mass stabilization, the shrinkage continued to increase. This
Table 5 Age and intensity of the main hydration peak of microcalorimetry curves

\begin{tabular}{|c|c|c|c|}
\hline Mortars & $\begin{array}{l}\text { Age of hydration } \\
\text { peak }(\mathrm{h})\end{array}$ & $\begin{array}{l}\text { Intensity of hydration } \\
\text { peak (mW/g of binder) }\end{array}$ & $\begin{array}{l}\text { Mixing temperature } \\
\left({ }^{\circ} \mathrm{C}\right)\end{array}$ \\
\hline C-100\% & 11.9 & 3.7 & \multirow{8}{*}{$\begin{array}{l}\text { Lab temperature } \\
\qquad\left(\sim 20^{\circ} \mathrm{C} \pm 2.0^{\circ} \mathrm{C}\right)\end{array}$} \\
\hline AFFC- $80 \mu \mathrm{m}-5 \%$ & 13 & 3.2 & \\
\hline AFFC-80 $\mu \mathrm{m}-20 \%$ & 12.5 & 3.1 & \\
\hline AFFC-100 $\mu \mathrm{m}-5 \%$ & 13 & 3.2 & \\
\hline AFFC-100 $\mu \mathrm{m}-20 \%$ & 12.8 & 3 & \\
\hline AFFC- $>100 \mu \mathrm{m}-20 \%$ & 12.5 & 3 & \\
\hline LF-5 \% & 13.1 & 3.6 & \\
\hline LF-20\% & 12.8 & 2.8 & \\
\hline
\end{tabular}



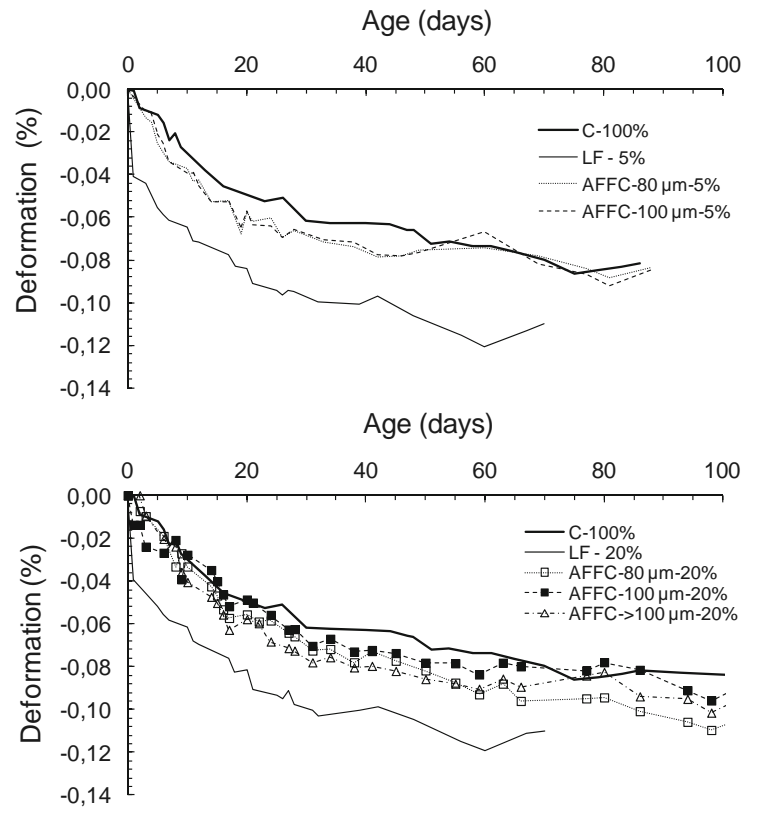

Fig. 5 Evolution of total shrinkage of mortars
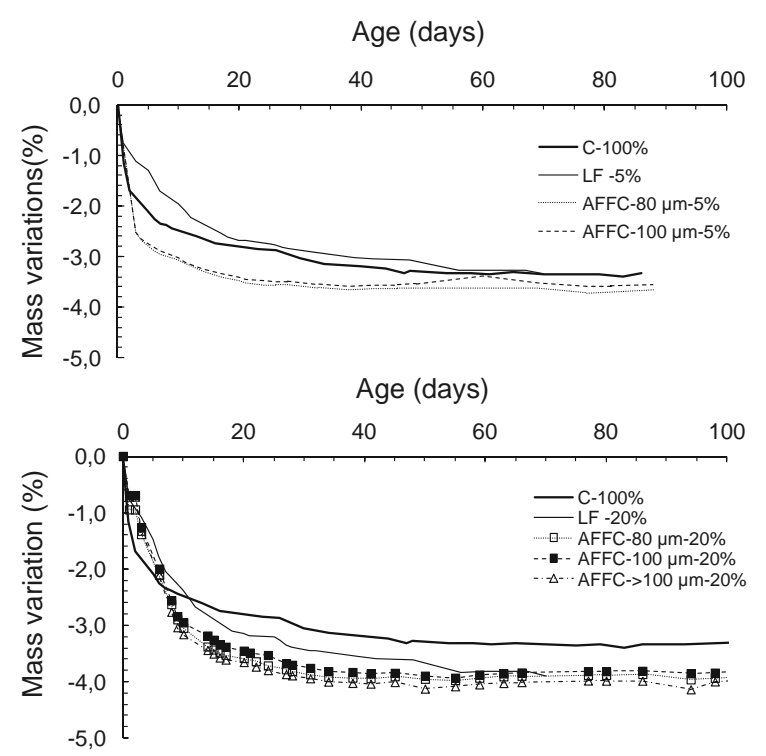

Fig. 6 Evolution of mass variation of mortars

phenomenon was probably related to the delayed creep deformations under the effect of capillary tension caused by the desiccation of mortars [17].
Concerning the influence of mortar compositions, we note that the total shrinkage of mortars containing fiber-cement was greater than that obtained for the control mortar, but remained below the shrinkage of mortars made with limestone filler (Fig. 5). The higher shrinkage of mortars with fiber-cement compared to the control mortar may first result from a more rapid loss of water, as shown in Fig. 6. This increased evaporation was likely related to the decrease in the Portland cement content in these mortars: thus, the amount of chemically-bound water during the hydration decreased, which generated an increasing of the free water fraction which can evaporate. Desiccation was therefore more intense and induced higher deformations of shrinkage. Moreover, the lower Young's modulus of mixtures made from fiber-cement (Table 6), also partly explains the higher deformations of these mortars compared to the reference mortar. For a fiber-cement dosage of $5 \%$, there was not appreciable significant influence of the fineness of fibercement on the shrinkage. The effect of this parameter was somewhat larger for the fiber content dosage of $20 \%$ : mortar AFFC- $80 \mu \mathrm{m}-20 \%$ had a "final" shrinkage value higher than that of mortars AFFC$100 \mu \mathrm{m}-20 \%$ and AFFC- $>100 \mu \mathrm{m}-20 \%$. Meanwhile, we note that for a given dosage of fiber-cement, the relative mass losses on mortar specimens were very similar, regardless of the fineness of the fibercement. The observed differences between shrinkage curves of mortars (AFFC- $80 \mu \mathrm{m}-20 \%$, AFFC$100 \mu \mathrm{m}-20 \%$ and AFFC- $>100 \mu \mathrm{m}-20 \%$ ) was not therefore explained by the amount of water evaporated, but could be related to the fineness of fiber-cement used. Indeed, it is likely that the higher shrinkage of the mortar (AFFC- $80 \mu \mathrm{m}-20 \%$ ) was due to a finer pore structure, in accordance with Laplace's law relating the intensity of capillary tension and pore radius. Similarly, the larger shrinkage of mortars with limestone filler could be explained by the higher fineness of this mineral addition (Fig. 2), which induced a finer porous network and therefore more intense mechanisms of capillary tension. Regarding our objective of fiber-cement valorization in cement matrixes, these results indicate that the substitution of cement with fiber-cement tends to increase the total shrinkage of mortars. This increase 
Table 6 Porosity accessible to water and dynamic Young's modulus of mortars measured at 28 days

\begin{tabular}{|c|c|c|c|c|}
\hline \multirow[t]{2}{*}{ Mortars } & \multicolumn{2}{|c|}{ Porosity (\%) } & \multicolumn{2}{|c|}{ Young's modulus (GPa) } \\
\hline & $\begin{array}{l}\text { Average } \\
\text { value }\end{array}$ & $\begin{array}{l}\text { Standard } \\
\text { deviation }\end{array}$ & $\begin{array}{l}\text { Average } \\
\text { value }\end{array}$ & $\begin{array}{l}\text { Standard } \\
\text { deviation }\end{array}$ \\
\hline C-100\% & 16.3 & 0.13 & 34.0 & 1.1 \\
\hline $\begin{array}{l}\text { AFFC-80 } \\
\mu \mathrm{m}-5 \%\end{array}$ & 19.5 & 0.52 & 32.7 & 0.56 \\
\hline $\begin{array}{l}\text { AFFC-80 } \\
\mu \mathrm{m}-20 \%\end{array}$ & 20.9 & 0.41 & 28.2 & 0.61 \\
\hline $\begin{array}{l}\text { AFFC-100 } \\
\mu \mathrm{m}-5 \%\end{array}$ & 19.3 & 0.2 & 32.6 & 0.78 \\
\hline $\begin{array}{l}\text { AFFC-100 } \\
\mu \mathrm{m}-20 \%\end{array}$ & 21.0 & 0.29 & 27.9 & 0.98 \\
\hline $\begin{array}{r}\text { AFFC }->100 \\
\mu \mathrm{m}-20 \%\end{array}$ & 21.4 & 0.25 & 26.0 & 0.86 \\
\hline LF-5 \% & 20.4 & 0.6 & 33.4 & 1.01 \\
\hline LF-20 \% & 20.7 & 0.23 & 31.5 & 0.59 \\
\hline
\end{tabular}

could be mitigated for example by optimizing the fineness of the ground product.

\subsection{Mechanical performance: compressive strength, flexural strength and Young's modulus}

The compressive strength and flexural strength of mortars at 28 days are presented depending on incorporation rate (5 and $20 \%$ ) of fiber-cement and limestone filler in Figs. 7 and 8 respectively. The partial replacement of cement with fiber-cement or limestone filler induced a decrease in compressive strength. This decrease was growing as the substitution rate of cement increased: it was between 12 and $19 \%$ for a substitution rate of $5 \%$ and between 22 and $35 \%$ for a substitution rate of $20 \%$. The reduction in compressive strength of mortar with binary binder was explained by their higher porosity (Table 6) and their lower Portland cement dosage, which induced a decrease in hydrate production.

For the same substitution rate, the mortars with fiber-cement showed a greater decrease in their compressive strength (Fig. 7) and their Young's modulus (Table 6) that mortars containing limestone filler. The fraction of cellulose fibers present in the fiber-cement powder (Fig. 1), lighter and less resistant to compression, was probably at the origin of this

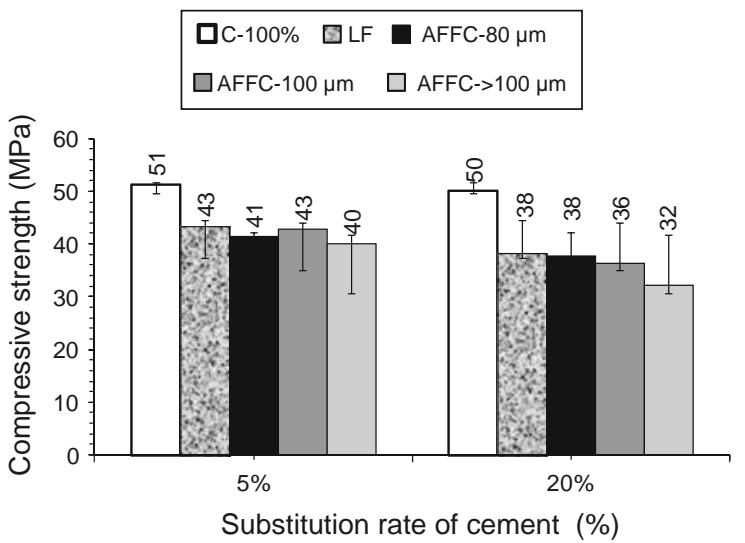

Fig. 7 Compressive strength at 28 days

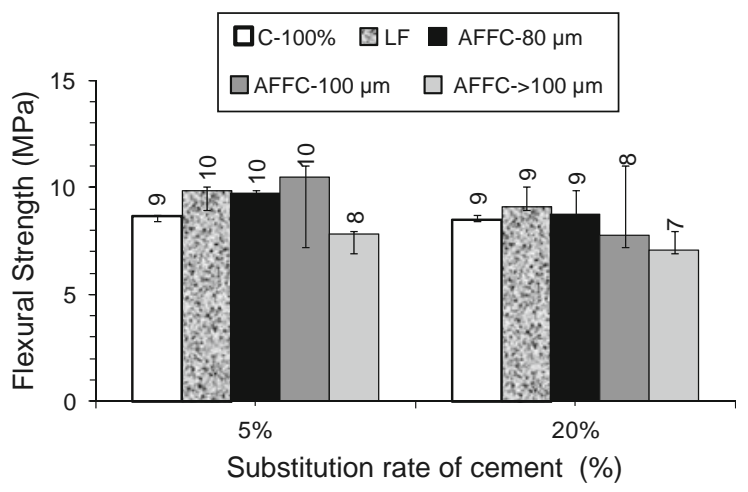

Fig. 8 Flexural strength at 28 days

difference in performance. We also note that the mortars incorporating the most coarsely ground fibercement (AFFC- $>100 \mu \mathrm{m}-5 \%$ and AFFC$>100 \mu \mathrm{m}-20 \%)$ had the lowest compressive strength and that mortars made with fiber-cement AFFC- $80 \mu \mathrm{m}$ and AFFC-100 $\mu \mathrm{m}$ presented mechanical properties substantially similar. In order to deepen the analysis of these results, it will be interesting to quantify the composition of each grade of crushed fiber cement. Indeed, it is possible that the preliminary grinding and sieving of fiber-cement induced a differential distribution of fibrous and cementitious phases depending on the density of these phases and the sieve size. This segregation may partly explain the lower mechanical properties of AFFC->100 $\mu \mathrm{m}$ -mortars, richer in fiber. In terms of flexural strength, mortars AFFC- $80 \mu \mathrm{m}-5 \%$ and AFFC-100 $\mu \mathrm{m}-$ $5 \%$ presented the highest performances, while mortars AFFC- $>100 \mu \mathrm{m}-5 \%$ and AFFC- $>100 \mu \mathrm{m}-$ $20 \%$ showed the lowest properties. It was also 
important to note that the decrease in performance associated to the increasing dosage of fiber-cement was less sensitive on the results of flexural strength than on compressive strength ones.

\section{Conclusions}

- From the experimental results and their analysis, the following conclusions can be drawn: The partial substitution of cement with fiber-cement causes an increase in dormant period of hydration of the binder comparable to that observed on the cement-limestone filler binder for the same substitution rate and water-on-binder ratio;

- The substitution of cement by fiber-cement tends to increase the total shrinkage of mortars. This increase could be mitigated for example by optimizing the fineness of ground product;

- The incorporation of fiber-cement causes a reduction of 14-35\% in the compressive strength of mortars at 28 days compared to the reference mortar. This decrease is higher than that observed on mortars incorporating limestone filler.

However, the strengths obtained are acceptable for structural applications.

A more detailed analysis of the composition of various size fractions of crushed fiber-cement and the measurement of durability indicators of mortars will be made in the following of this study. The results presented are valid only for the cementitious systems studied and should be completed on other of mortar and concrete mixes.

To better understand the impact of the effect of asbestos-free fiber-cement waste as a partial substitute of Portland cement, others studies are underway to observe the feasibility of these materials on concrete.

\section{References}

1. Müller A, Schnellert T, Seidemann M (2011) Material utilization of fibre cement waste. ZKG Int 64:60-72
2. Tam WYV, Tam CM, Wang Y (2007) Optimization on proportion for recycled aggregate in concrete using twostage mixing approach. Constr Build Mater 21:1928-1939

3. Hoffmann C, Schubert S, Leemann A, Motavalli M (2012) Recycled concrete and mixed rubble as aggregates: influence of variations in composition on the concrete properties and their use as structural material. Constr Build Mater 35:701-709

4. Maier PL, Durham SA (2012) Beneficial use of recycled materials in concrete mixtures. Constr Build Mater 29:428-437

5. Soutsos MN, Tang K, Millard SG (2011) Use of recycled demolition aggregate in precast products, phase II: concrete paving blocks. Constr Build Mater 25:3131-3143

6. Stehlíka M (2013) Testing the strength of concrete made from raw and dispersion-treated concrete recyclate by addition of additives and admixtures. J Civ Eng Manage 19:107-112

7. NF EN 197-1 (2000) Cement-part 1: compositions, specifications and conformity criteria for common cement. European Committee for Standardization, Brussels

8. NF EN 196-1 (2006) Methods of testing cement-part 1: determination of strength. European Committee for Standardization, Brussels

9. NF P 18-452 (1988) Bétons-Mesure du Temps d'Ecoulement des Bétons et des Mortiers aux Maniabilimètres. AFNOR

10. NF P 15-433 (1994) Méthodes d'Essais des CimentsDétermination du Retrait et du Gonflement. AFNOR

11. AFPC-AFREM 11-12 (1997) Compte-Rendu des Journées Techniques. Durabilité des Bétons, Toulouse, pp 125-134

12. NF P 18-414 (1993) Essais des Bétons-Essais Non Destructifs. Mesure de la Fréquence de Résonance Fondamentale. AFNOR

13. ASTM C1679 (2009) Standard practice for measuring hydration kinetics of hydraulic cementitious mixtures using isothermal calorimetry. ASTM International, West Conshohocken, PA

14. Mounanga P, Khokhar MIA, El Hachem R, Loukili A (2011) Improvement of the early-age reactivity of fly ash and blast furnace slag cementitious systems using limestone filler. Mater Struct 44:437-453

15. Ballim Y, Graham PC (2009) The effects of supplementary cementing materials in modifying the heat of hydration of concrete. Mater Struct 42:803-811

16. Baroghel-Bouny V, Mounanga P, Khelidj A, Loukili A, Rafaï N (2006) Autogenous deformations of cement pastes: part II. W/C effects, micro-macro correlations, and threshold values. Cem Concr Res 36:123-136

17. Grasley ZC, Leung CK (2011) Desiccation shrinkage of cementitious materials as an aging, poroviscoelastic response. Cem Concr Res 41:77-89 